\title{
Conceptual and grammatical characteristics of argument alternations: the case of decausative verbs*
}

HOLDEN HÄRTL

Abstract

In this paper the grammatical and conceptual properties of decausative verbs of the type The plate broke are explored from the viewpoint of a model of language production that systematically upholds the distinction between grammatical and extralinguistic information. In the constructions under consideration, an agentive entity — just like in passives — is suppressed by grammatical means. The first part of the paper centers around the question of whether an implicit entity can be derived from linguistic form, that is, whether there is any grammatical/lexical indication of an entity causing the result state. On the basis of several grammatical tests it is argued that decausatives in comparison to passives do not grammatically encode any causal component. In the second part the conceptual structures underlying decausative verbs are determined. An investigation of the information-structural constellations suggests that with decausatives no causal entity is introduced into the discourse. Instead, the implicit causality intuitively understood with these verbs is based on the concept of abstract causation, which does not involve a sortally or referentially specified entity. Thus the conceptual structures underlying decausatives and nonalternating inchoatives as burst prove to be identical. Finally, the regularities behind the alternation are defined. An examination of event-structural and object properties suggests that alternating verbs are the ones that can denote an independent change in an inherent object property and a canonical activity that initiates the corresponding change.

\section{The phenomenon}

One of the most challenging aspects in modeling language production is the determination of the mapping mechanisms that operate between the extralinguistic and the grammatical level. A central question with regard 
to this issue is how to systematically define similar meanings that are realized in divergent ways in grammar. In this context the question of why and how certain pieces of information are left implicit has gained more and more attention in studying procedural aspects of the mapping mechanisms (cf. Mauner and Koenig 2000, see also Härtl 2003; Härtl and Witt 1998). The divergence in grammatical realization meant here is often associated with some kind of suppression of arguments as in the case of passive structures:

(1) a. The enemy sank the ship.

b. The ship was sunk.

In passive structures there is evidence that the suppressed argument is still interpreted (or present in argument structure) although it is not given any referential value. Structures like those in (2) support this well-known assumption (cf. Roeper 1987; Levin and Rappaport Hovav 1995):

(2) The ship was sunk in order PRO to collect the insurance.

In the subordinate clause in (2) a nonovert PRO form, which functions as thematic agent, is understood to be coreferential with the implicit argument of the matrix clause. This constellation changes if PRO is replaced by an overt noun phrase with a case-marking preposition:

(3) The ship was sunk in order for John to collect the insurance.

Here the logical subject John of the subordinate sentence is not necessarily coreferential with the implicit argument of the matrix clause. Evidence comes from structures that explicate the implicit argument of the passive by means of a by phrase introducing an entity distinct from the logical subject of the subordinate sentence:

(4) The ship was sunk by the pirates in order for John to collect the insurance.

None of the options just sketched is given with intransitive, decausative ${ }^{1}$ complexes, in which - just like in passives - an entity is suppressed by means of a grammatical operation. In (5) PRO cannot be interpreted, which seems to give us evidence that there is no controlling constituent existent in the matrix clause:

(5) a. *The ship sank in order to collect the insurance.

b. *The plate broke in order to collect the insurance.

c. *The door closed in order to keep out the rats.

Another explanation for the ungrammaticality of (5) takes into consideration the specific semantic properties of purpose clauses introduced by 
in order to. They require an (intentionally acting) agentive entity to control the PRO element. Nonagentive entities cannot control PRO in purpose clauses. That is why the sentences in (6) containing a theme rather than an agent are unacceptable whereas those in (7) are grammatical:

(6) a. ??John knew the right answer in order to rescue Mary.

b. ??John adored Mary in order to impress Ann.

c. ??John saw the painting in order to learn something about the painter.

(7) a. John gave the right answer in order to rescue Mary.

b. Mary amused John in order to impress Ann.

c. John looked at/studied the painting in order to learn something about the painter.

With regard to (5) then the ungrammaticality could also be attributed to the fact that there is no implicit agentive entity involved in the matrix clause whereas in the passive in (2) this seems to be the case. Notice also that neither in the passive nor in the decausative does the event structure change. The telicity feature is preserved, that is, both express events with an inherent endpoint.

In principle, the explanatory aspects just sketched are of a grammatical nature and do not give us independent evidence for the conceptual, that is, extralinguistic properties of the alternating structures. The question now is whether we can find any indication of the conceptual status of the entities demoted grammatically. Informally speaking, we need to find out whether the entities in question are present in the underlying conceptual structure of the expressions.

Against this background, the decausative alternation in German will be dealt with in this paper. The discussion centers around two aspects. First, the specific lexical and the underlying extralinguistic properties of decausativized verbs are determined. Several existing analyses are considered and checked for their explanatory adequacy from the vantage point of a model of language production. In this context the lexical and the conceptual status of the argument affected by the suppression is explored. The discussion of this issue focuses on the question of whether the conceptual structure of decausativized expressions such as The plate broke contains causal information indicating the entity responsible for causing the corresponding events. In this context, passives and decausative structures, often considered being similar in meaning, are compared. Finally, the specific properties of verbal expressions that allow decausativization are explored in contrast to those verbs that cannot decausativize. From a more procedural viewpoint, the goal of this paper is to find an answer 
to the question of what a speaker knows about an implicit event participant and at which stages of processing this knowledge is represented. Before these questions can be addressed, a theoretical framework in which the distinction between grammatical and extralinguistic information is clearly determined has to be established. I shall turn to this in more detail in the next section.

\section{Generating a grammatical expression}

Here a serial modular model is assumed that strictly differentiates a purely linguistic from a conceptual level of language processing (cf. Bierwisch and Schreuder 1992; Härtl 2001a; Herweg and Maienborn 1992; Levelt 1989). The conceptual knowledge base (CKB) consists of subsystems organizing language-independent knowledge structures, which are used by the conceptualizer ${ }^{2}$ in order to construct a prelinguistic ${ }^{3}$ conceptual structure. This preverbal message structure encodes the propositional content CS of the linguistic output, on the one hand, and referential and information-structural values of the entities involved in an event conceptualization, on the other. The latter type of information is associated with context sensitive constellations, which as such are encoded in a contextual background structure CT. In the model used here, in CT the referential identity of entities in discourse is represented by the two features SORT and REF, which reflect the sortal and referential value of the entities involved in the conceptual structure. SORT determines whether the type of an object involved in CS is restricted as to what the conceptual-ontological property of this object is. The feature REF encodes the contextual value or the potential of the object to be identified in a discourse universe such that in the linguistic system, for example, a corresponding definiteness marker is selected. For instance, the identity of an unrealized internal argument as it can be assumed with structures like John marries must be sortally fixed (+SORT[human]) but referentially vacuous ( $\neg$ REF) so that it does not attain any discourse value. We get a different picture with structures like John heard something, where the sortal identity of the internal argument is unspecified ( $\neg$ SORT) but gains a referential value $(+\mathrm{REF})$ such that it can be referred to in future discourse. Furthermore, in the $\mathrm{CS} / \mathrm{CT}$ complex (or its decompositional structure, respectively) the two prototypical thematic relations proto-agent and proto-theme are established on the basis of a rule system which processes primitive conceptual features (movement and causality) of entities thus reflecting the propositional function of the entities that 
are embedded in the conceptual structure (cf. Dowty 1991, 1998; Härtl 2001a, 2001b).

Movements or CHANGES of entities represent events. So CHANGES must be associated with the event structural properties of telicity and duration. In Härtl (2001a) this is done by a network that relates any type of CHANGE to types of events that are specified temporally. An event like John is dancing implies a CHANGE (instantiated by the movement) in general, which has to be further specified according to the properties of its atelicity ( $\neg$ TEL) and its duration (+DUR). This information is visible in grammar and therefore encoded directly in the lexicosemantic representation SR (see below) generated by the linguistic system. In order to assign appropriate thematic relations, the conceptualizer has to calculate the two cognitively based features ${ }^{4}$ CAUSE and CHANGE, which are attached to salient entities in the discourse set. Entities are assigned thematic functions by means of a statistical method - similar to Dowty's (1991) conception of thematic role assignment — which embeds them into conceptualized event representations. For example, in the event conceptualization of John killed a flea, the two entities involved change in some way, however, it is only John who causes an event (the dying of the flea). Thus the corresponding entity (John) wins the competition for functioning as proto-agent in the event conceptualization.

The mapping between the conceptual and the linguistic representations is achieved by a specific interface mechanism — the thematic processor (TP). ${ }^{5}$ TP operates on information that is associated with the strictly extralinguistic thematic relations encoded in the CS/CT complex and relates this information to a grammatical representation of the linguistic system (or the formulator to follow Levelt's terminology). According to Bierwisch and Schreuder (1992), the linguistic system produces a lexicosemantic representation SR encoding all meaning components of the expression that are related to grammatical aspects and that can be derived from the overt, morpho-syntactic parts of it. ${ }^{6}$ The strictly linguisticallybased SR is generated on the basis of the lexicon, which organizes the context-independent meaning of lexical entries according to their argument structural, event structural, and idiosyncratic aspects. Decompositional semantic constants such as the predicates CAUSE, DO, or BECOME encoded in the lexical entries and operated on in SR are directly linked to the syntactic representations of the linguistic system. By means of the semantic constants the thematic constellations explicitly represented in the $\mathrm{CS} / \mathrm{CT}$ complex are implicitly (configurationally) reflected in SR. In contrast, the expression's event-structural features (the Aktionsart) are explicitly encoded in SR. These are grammatically relevant 
and from them the extralinguistic thematic constellations can be inferred (cf. Härtl 2001a).

Against this background, the characteristics of decausative verbs have to be defined by answering the following questions:

1. What are the lexical properties encoded in the SR of decausative verbs?

2. Does the SR of decausative verbs contain a causal component?

3. What is the conceptual and the referential status of the causal entity demoted in grammar? Is it still a proto-agent?

4. Is there any lexical and conceptual difference between alternating decausative verbs and nonalternating intransitive change-of-state verbs?

5. What are the underlying conceptual conditions that determine the potential of verbs to alternate?

\section{Lexical and conceptual properties of decausative verbs}

\subsection{Two lexical approaches}

Decausativity is a notion that is related to the semantic properties of a subgroup of unaccusative intransitive verbs. Consequently, all decausative verbs are considered unaccusative whereas not all unaccusative verbs are decausative. The following examples, all intransitive verbs, illustrate this grouping:
a. UnACCUSATIVE/-DeCAUSATIVE:
Maria fiel.
'Maria fell.'
b. UnACCUSATIVE/ + DECAUSATIVE:
Der Teller zerbrach.
'The plate broke.'
c. UNERGATIVE:
Petra weinte.
'Petra cried.'

Unaccusative verbs can be identified by (among other things) their specific behavior in the perfect auxiliary selection. While unaccusative verbs in German select the be auxiliary, unergative verbs realize the perfect with a form of have. Furthermore, the impersonal passive is only possible with unergative verbs. The specific properties of unaccusative verbs have led to the conclusion that the syntactic subject of unaccusative complexes is base-generated as the direct object, which thus bears a nonagentive thematic role and which has to move to the subject position because 
unaccusative verbs cannot assign accusative case (cf. Burzio 1986; Levin and Rappaport Hovav 1995; Perlmutter 1978). Kaufmann (1995) in her explicitly nonsyntactic, semantically motivated approach to unaccusativity analyzes unaccusative verbs as dynamic theme predicates (DTP). According to her analysis, theme predicates denote an object-defining property. An object-defining property such as color or shape of an object is considered an obligatory (ontological) quality that is relevant to the conceptualization of objects and that cannot be discarded. A theme predicate is dynamic if it denotes a change in an object-defining property. So verbs as redden or melt are unaccusative for they denote changes in object defining properties such as the state of matter. Kaufmann argues that this conceptual information is encoded lexically, that is, in the SR of unaccusative verbs.

Kaufmann's DTP analysis of unaccusative verbs would answer the first question given above if it covered all instances of decausative verbs. However, there are cases of decausative verbs that do not necessarily denote changes in an object-defining property:

(9) a. Der Teller zerbrach.

'The plate broke.'

b. Das Material verbrannte.

'The material burnt.'

c. Das Seil zerriss.

'The rope tore.'

I doubt whether the complexes in (9) really denote changes of a property that is relevant for the conceptualization of the objects in question. The problem here is that one cannot really determine the initial state that is valid before the actual change of state. The only option given is to define the initial state as a negation of the posterior state. It is in this sense that properties such as "being broken" or "being torn" are opaque with regard to an attribute "object defining." On the other hand, there are similar transitive verbs also denoting a change of state which, however, do not alternate:

(10) a. *Das Gemälde zerstörte.

'The painting destroyed.'

b. *Die Dose zerdrückte.

'The can crushed.'

c. *Das Brot zerschnitt.

'The bread cut up.'

Intuitively, with regard to a potential object-defining property there is no profound difference in meaning between the verbal complexes under 
(9) and those in (10). This shows that so far there seems to be no independent evidence other than unaccusativity itself for determining the group of decausative verbs being a subgroup of unaccusative verbs. Therefore the DTP analysis is not suitable for exclusively defining the lexical properties of decausative verbs.

A different approach to the lexical properties of alternating causative verbs is taken by Levin and Rappaport Hovav (1995). They argue that verbs allowing a decausativization express a change of state coming about without the intervention of a volitional agent. Instead of a volitional agent, alternating verbs allow NATURAL FORCES to cause the change of state in the affected object:

(11) a. John zerbrach die Fensterscheibe.

'John broke the window.'

a.' Der Sturm zerbrach die Fensterscheibe.

'The storm broke the window.'

a." Die Fensterscheibe zerbrach.

'The window broke.'

(12) a. John zerschnitt das Brot.

'John cut the bread.'

a.' *Das Messer zerschnitt das Brot.

'The knife cut the bread.'

a." *Das Brot zerschnitt.

'The bread cut.'

For German this proposal is weakened by the existence of verbs such as erschlagen or zerstören, which can denote a change of state caused by a natural force but which cannot detransitivize:

(13) a. Der Fels erschlug das Reh.

'The rock killed the deer.'

a.' *Das Reh erschlug.

'The deer killed.'

b. Die Flut zerstörte das Dorf.

'The flood destroyed the village.'

b.' *Das Dorf zerstörte.

'The village destroyed.'

Another proposal made by Levin and Rappaport Hovav (1995) concerns the specificity of the state in which the event described by causative verbs results. The authors argue that decausativization is possible with verbs that specify a result state and not an activity that causes this result. Problematic again are nonalternating verbs such as zerstören 'destroy' or zerkleinern 'to make smaller', which do not seem to specify an activity 
causing a result state. This is supported by the constructions in (14), which contain means clauses explicating the nonspecified causing activity. An explication of this activity is less acceptable with verbs which inherently specify the activity causing the result state (cf. [15] and Härtl 2001a):

(14) a. Hans hat den Garten durch maßlose Bewässerung zerstört. 'Hans has destroyed the garden by immoderate watering.'

b. Hans hat das Material durch Hacken zerkleinert.

'Hans has made smaller the material by hacking (it).'

(15) a. ??Peter hat das Holz durch Entzweihauen zerhackt.

'Peter has chopped up the timber by breaking it apart.'

b. ??Peter hat den Stoff durch Schnippeln zerschnitten.

'Hans has cut apart the fabric by snipping.'

Although — as is shown by the means clauses - the verbs in (14) do not inherently specify an activity causing a result state, they do not allow a decausativization. In contrast, the verbal complexes in (15) do explicate a causing activity and - in accordance to the prediction of Levin and Rappaport Hovav - also do not decausativize. Thus the specificity of the causing activity expressed by (non-)alternating verbs seems to be a sufficient but not necessary condition for the lexical properties that determine the option of decausativization. Although the authors' proposal is attractive because of its systematic nature the issue is much more complex, as we will see in section 3.4.

The outcome of the argumentation in Levin and Rappaport Hovav (1995) is relevant to the questions asked in this paper in two ways. First, the authors argue that the demoted argument is LEXICALLY BOUND, which suggests that it is still present in the lexico-semantic structure SR of the expressions in question:

(16) intransitive break:

$\lambda y \varnothing x$ e [e INST[CAUSE x, BECOME [BROKEN(y)]]] $]^{7}$

A byproduct of Levin and Rappaport Hovav's analysis is the lexical anchoring of the causal constant in the SR. This implies that decausative complexes still denote (externally) caused events. Thus, both the transitive and the intransitive verbal realization are considered mere lexical variants of one and the same proposition. This is what I shall argue against in the next section.

\subsection{Decausatives are lexical noncausatives}

I agree with Piñón (2000, 2001b) in his assessment that decausative verbs lack a causal semantics. This means in the context of the model assumed 
here that a lexical constant CAUSE cannot figure in the lexico-semantic representation SR of these verbs. Related to this is the fact that a corresponding argument (i.e. the causer) cannot be present in the respective SR. The corresponding analysis covers cases where one could assume a nonagentive cause also, that is, an unintentionally acting entity such as a natural force causing the change of state. This implies that neither nonintentionality or nonagentivity can be considered crucial features of the class of alternating decausative verbs. As will be discussed below, decausative verbs do not express either agentivity or causality as compared to the corresponding (short) passives, which denote a causal meaning in any case but do not specify agentivity. Thus, wherever reasonable, adequate tests using passives as a control have to involve structures expressing both nonagentive and agentive entities.

What evidence do we have for the assumption that, with the verbs in question, no causative component is reflected in grammar? ${ }^{8}$ First of all, decausative verbs usually do not allow the grammatical explication of the suppressed argument, which is indeed possible with passives whose SR does encode causativity:
a. Das Seil wurde von Peter zerrissen.
'The rope was torn by Peter.'
a.' Das Seil wurde vom Wind zerrissen.
'The rope was torn by the wind.'
b. *Das Seil zerriss von Peter.
'The rope tore by Peter.'
b.' *Das Seil zerriss vom Wind.
'The rope tore by the wind.'

This finding is supported by the impossibility of modifying a potential causing activity with adverbial expressions that relate to the thematic (agentive) content of the demoted argument. Again this option is given with passives:

(18) a. Die Schüssel wurde absichtlich/leichtsinnigerweise/gerne zerbrochen.

'The bowl was broken on purpose/carelessly/willingly.'

b. *Die Schüssel zerbrach absichtlich/leichtsinnigerweise/gerne.

'The bowl broke on purpose/carelessly/willingly.'

Furthermore, the occurrence of the dativus (in-)commodi is interpreted differently depending on the type of the reduced verbal complex. While in passives, the argument assigned to the free dative can never be interpreted as causing the corresponding change of state, the dative in decausatives can be interpreted in a causal sense: 
(19) a. Das Material wurde ihm verbrannt.

'The material was burnt on him.'

$\rightarrow$ he caused the material to burn $=$ impossible

b. Das Material verbrannte ihm.

'The material burnt on him.'

$\rightarrow$ he (unintentionally) caused the material to burn $=$ possible

The difference in interpretation of the dative can be attributed to the fact that in passives the causative component is still present in the semantic representation and therefore cannot be replaced by a distinct causal entity. Otherwise two causal relations would clash. In contrast, (19b) suggests that a causal interpretation of the dative is possible with decausatives: a causal component can be reintroduced into the semantic representation for there is no such component present in the decausative complex itself. ${ }^{9}$

A corresponding lexical representation SR must reflect this difference. According to Olsen (1997) and Wunderlich (1996) the free dative is generated lexically through supplying an additional predicate to the SR of the verb. This predicate POSS indicates an abstract (negative or positive) possessive relation between two entities: the possessor $(=\mathrm{z})$ realized as dative and the possessed $(=\mathrm{y})$. Correspondingly, the SR of transitive zerbrechen is to be formulated as follows. As will also be shown below the only difference between active and passive lies in the binding of the external argument, that is, the agent:

a. Peter zerbrach ihm den Teller. ${ }^{10}$

'Peter broke the plate on him.'

$\lambda y \lambda z \lambda x \lambda e$ [e INST [CAUSE x, BECOME [BROKEN(y)]] $\& \neg \operatorname{POSS}(\mathrm{z}, \mathrm{y})]]$ (the plate) (he) (peter)

a.' Der Teller wurde ihm zerbrochen.

'The plate was broken on him.'

$\lambda y \lambda z \exists x \lambda e$ [e INST [CAUSE x, BECOME [BROKEN(y)]] $\& \neg \operatorname{POSS}(\mathrm{z}, \mathrm{y})]]$ (the plate) (he)

In contrast, in decausative structures an additional predicate CAUSE is supplied to the SR of the noncausative complex thus eliciting the causal reading of the dative:

(21) Der Teller zerbrach ihm.

'The plate broke on him.'

$\lambda y \lambda z \lambda e[e \operatorname{INST}[\operatorname{BECOME}[\operatorname{BROKEN}(\mathrm{y})]] \&$

$\operatorname{CAUSE}(z, \neg \operatorname{POSS}(z, y))]$ ] (the plate) (he)

This representation adequately encodes the potential interpretations 
related to the grammatical structure in question. Consider the following representation, which might be also conceivable:

(22) Der Teller zerbrach ihm.

'The plate broke on him.'

$\lambda y \quad \lambda z \quad \lambda e$ [e INST [CAUSE $x_{i}, \operatorname{BECOME~[BROKEN(y)]]~\& ~}$ $\left.\left.\neg \operatorname{POSS}\left(\mathrm{z}_{\mathrm{i}}, \mathrm{y}\right)\right]\right]$ (the plate) (he)

In this alternative representation for a decausative complex containing a free dative, in contrast to passives, the external argument (x) of CAUSE still present in this SR is not existentially bound but simply remains unbound as a free variable and is thus dependent on a purely conceptual interpretation. In addition, the unbound argument variable is marked as referentially identical to the negated possessor (z), which would be realized as dative. This representation, however, does not generate the correct inferences about the expressions in question. First, the representation in (22) implies that the unbound argument figures as an intentionally acting agent, for with animate objects the CAUSE component in this lexical configuration canonically induces this interpretation. Thus (22) must produce an incorrect interpretation, for intentionality can never be a possible meaning component of decausative expressions containing a free dative. This is illustrated by the ungrammaticality of constructions containing a free dative and a purpose clause, which obligatorily require an intentional agent:

(23) *Der Teller zerbrach ihm, um die Versicherung zu kassieren.

'The plate broke on him in order to collect the insurance.'

Supporting evidence for the inadequacy of the representation in (22) comes from other change-of-state verbs, which can be used intransitively only. With them the dative renders an interpretation that is parallel to the interpretation of the dative in alternating verb complexes. With both types of dative argument can be understood as causing the resulting state. Consider these obligatorily intransitive examples:

(24) a. Das Kartenhaus zerfiel ihm.

'The house of cards collapsed on him.'

b. Der Ballon zerplatzte ihm.

'The balloon burst on him.'

As these verbs do not have a transitive variant, an SR as in (22), which is based on the transitive form of the verb in question, cannot be a possible description of their lexical meaning. It would be an unwelcome result of the analysis to have to assign different lexical representations to intransitive alternating and to intransitive nonalternating verbs, which 
are in fact identical in their abstract meaning and behave alike in grammar. Furthermore, the free dative does not always have to be interpreted as the causer of the result state of the affected object, although (22) suggests this. Consider a corresponding example in which the result state is caused by an external entity:

(25) Der Teller zerbrach ihm, weil der Sturm das Fenster aufdrückte. 'The plate broke on him because the storm opened the window.'

Although this is certainly not a canonical interpretation of the dative, it shows that the actual causer and the negated possessor do not have to be identical. Considering the lexical representation under (21) appropriate now, in expressions like (25) the causer argument $\mathrm{z}$ of the free predicate CAUSE must remain unbound and has to be interpreted through contextual information as it is supplied by the subordinate because sentence in (25). In any case, according to the linking rules the affected object as the most deeply embedded argument is base-generated as the direct object thus producing the typical unaccusative structure.

Similar to the free dative, modification with a reflexive by phrase can reintroduce the causal component into the semantic representation of decausative verbs but not of causative passives, which again suggests that the causal component is lexically present in passives but not in decausatives:

a. Der Teller zerbrach von selbst.

'The plate broke by itself.'

b. *Der Teller wurde von selbst zerbrochen.

'The plate was broken by itself.'

Similar examples are taken as evidence for the causative nature of decausatives by Levin and Rappaport Hovav (1995) in accordance with Chierchia (1989). The authors argue that the adverbial by itself modifies the cause being identified as the theme-argument, which means that the argument of CAUSE and the argument of the resulting state are coreferential (cf. [16]). As Piñón (2000) notes, however, this would again result in wrong inferences about the meaning of decausative complexes, for (26a) does not mean "the plate intentionally did something that caused it to get broken."

In general, the structures discussed above give enough evidence that decausative complexes are truly noncausative on the grammatical level of SR and do not express remnants of the related causative variant. Thus instead of anchoring a causal constant in decausatives as in (16) an SR as it is given in (27) adequately reflects the relevant grammatical constellations: 
(27)

intransitive break:

$\lambda y$ de [e INST [BECOME [BROKEN(y)]]]]

The SR in (27) encodes all grammatically relevant aspects of the verbs in question: they are one-place predicates denoting a change of state, and the denoted event is punctual in its intrinsic temporal structure. ${ }^{11}$ Summarizing this section, the crucial point is that only in passives but not in decausatives can the implicit event participant and the causalmeaning component be derived from linguistic form. Having identified the grammatical form of decausativized verbs, now their conceptual properties need to be determined. I shall addresss this issue in the next section devoted to the qustion of whether and which type of a potential causal relationship is encoded extralinguistically on the level of CS/CT.

\subsection{Conceptual properties of decausatives}

Conceptually, information structural properties of expressions are encoded in the CT complex of a preverbal message. CT organizes entities (i.e. ontological objects as well as events) with regard to their referential status in the expression in order to match the speaker's knowledge about the previous discourse against the content of the communicative act being planned. Thus, the grammatical realization of a proposition CS has to systematically relate to the information given in CT. In principle, in two distinct situational contexts, two identical propositions CS may be generated with differing truth conditions and with distinct grammatical, that is, lexico-semantic and syntactic realizations. A difference in information structure (to be more specific: in CT) of one and the same proposition has its reflex on the grammatical levels such as the syntactic level as in the case of passives, where a referentially nonsalient entity is denoted by a specific (morpho-)syntactic means, or the phonological level, where prosodic constellations express the referential status of the corresponding argument.

With regard to the $\mathrm{CS} / \mathrm{CT}$ complex underlying decausative verbs, there is fairly obvious evidence that neither a specific nor an implicit entity involved in an intentional action is introduced into the current discourse:

(28) a. Der Teller zerbrach.

'The plate broke,'

??Aber es war nicht Peter, sondern Maria. 'but it wasn't Peter but Maria.'

b. Das Papier verbrannte.

'The sheet burnt,' 
??Aber es war nicht Peter, sondern Maria. 'but it wasn't Peter but Maria.'

The unacceptability of the structures in (28) can be attributed to the fact that the negative contrastive structure introduced by aber inadequately focuses on a causal entity that is not present in the current discourse set. Therefore with the contrastive structure, a specific referential status of an entity (Peter) is presupposed that does not match the truth conditions of the decausative structure. Note that the degree of acceptability, at least in German, does not increase dramatically with contrasting expressions that denote a natural force (see [29] below). However, these should be acceptable if alternating (externally caused) change-of-state verbs in their intransitive use are characterized by their potential to allow natural forces or instruments as causal entities (cf. Levin and Rappaport Hovav 1995, see also section 3.1 above):

(29) a. Der Teller zerbrach.

'The plate broke,'

??Aber es war nicht das Erdbeben, sondern der Wind. 'but it wasn't the earthquake but the wind.'

a.' Der Teller zerbrach.

'The plate broke,'

??Aber es war nicht der Hammer, sondern die Zange. 'but it wasn't the hammer but the pliers.'

b. Das Papier verbrannte.

'The sheet burnt,'

??Aber es war nicht die Sonneneinstrahlung, sondern die Herdplatte.

'but it wasn't the sunlight but the hotplate.'

Note also that the contrastive sentences become acceptable as soon as the noun phrase is replaced by a causal prepositional phrase headed by wegen 'because of' to denote a causal entity. ${ }^{12}$

(30) a. Der Teller zerbrach.

'The plate broke,'

Aber es war nicht wegen dem Erdbeben, sondern wegen dem Wind.

'but it wasn't because of the earthquake but because of the wind.'

b. Das Papier verbrannte.

'The sheet burnt,' 
Aber es war nicht wegen der Sonneneinstrahlung, sondern wegen der Herdplatte.

'but it wasn't because of the sunlight but because of the hotplate.'

The examples in (30) give us further evidence that there is no specific causal entity - neither an intentional agent nor a natural force - being introduced with the decausative change-of-state verbs in question. This is so because wegen sentences like the ones above can also be used with nonalternating change-of-state-verb complexes. ${ }^{13}$ With these, however, no specific causal component should be represented in their conceptual representation (see the discussion below).

(31) a. Der Apfel verfaulte.

'The apple rotted,'

Aber es war nicht wegen der Feuchtigkeit, sondern wegen der fehlenden Luft.

'but it wasn't because of the humidity but because of the missing air.'

b. Die Hütte zerfiel.

'The hut decayed,'

Aber es war nicht wegen dem Regen, sondern wegen dem Wind.

'but it wasn't because of the rain but because of the wind.'

Consequently, there is no reason to assume a causal component with alternating decausative verb complexes in (30). In this sense, the tests suggest that the semantics of alternating and nonalternating intransitives is parallel, which I will argue in more detail in the following section.

The discussion above is based on the assumption that the contrastive sentences in (28) and (29) are unacceptable because no causal entity is introduced with the decausative change-of-state verbs. Hence, a different picture emerges with structures that involve an indefinite pronoun or an implicit (and specific ${ }^{14}$ ) causal entity as in passives:

(32) a. Der Teller wurde zerbrochen.

'The plate was broken,'

Aber es war nicht Peter, sondern Maria.

'but it wasn't Peter but Maria.'

b. Jemand verbrannte das Papier.

'Somebody burnt the sheet,'

Aber es war nicht Peter, sondern Maria.

'but it wasn't Peter but Maria.'

Here, the corresponding entity can be contrasted with another entity, 
which shows that in the underlying CS/CT complex, in contrast to the decausative structures, a causal entity is indeed indicated. So far, however, I have only discussed issues of reference: while passives denote a causal relation between two concrete entities - an (implicit) agent and a theme - as well as a specific activity causing the result state, decausatives do not denote either piece of information. The question still left unanswered is whether a causal relationship is conceptualized at all in decausatives or whether there is some other type of causality involved in the underlying preverbal message. At first glance the latter assumption seems to match the intuition about the structures in question: even if no specific causing entity or action is expressed in decausatives something must be responsible for the change of state in the affected entity. This intuition is not based on mere introspection. We know from several studies on the perception of changes in objects that changes in general are perceived as caused by some entity, though in the actual situation there is no overt or visible causal relation between the entities involved (cf. Houssiadas 1964).

In principle, as has already become apparent, there are several kinds of causes to be distinguished. I shall concentrate on two types here. The corresponding concepts differ with regard to the characteristics of the cause involved in a chain of cause and effect. The first one indicates the direct source of an effect and is generally known as causa efficiens (or Wirkursache in German). The second type indicates that an effect can come about to serve a certain purpose (causa finalis or Zweckursache). An example of a causal relation containing a causa efficiens would be something like John frightened Mary because he was aggressive, which expresses John's aggressiveness as the direct source of a result, namely Mary's fear. A causa finalis is realized in expressions like John frightened Mary because he wanted to impress Ann, where it is not John's intention to impress Ann that directly causes Mary's fear. John's intention rather figures as a purpose that induces John to do something to achieve a corresponding result, namely Mary's being frightened. Both types of causes are instantiated by the same pragmatic function, for both indicate a factual causal relation between two content units, which is interpreted through a reductive reasoning operation (cf. Härtl 2001a; Lang 2000; Pasch 1983).

The two types can be reflected in grammar in German. Typically, with causative verbs such as kill subordinate causal sentences introduced by weil 'because' can only denote a causa finalis, that is, the purpose of the entire state of affairs expressed in the matrix clause (cf. [33b]). A subordinated causa efficiens giving a reason for the resulting state in the matrix clause as in (33a) usually does not occur in this constellation: ${ }^{15}$ 
a. CAUSA EFFICENS:

??John tötete die Ratte, weil er sie trat.

'John killed the rat because he kicked it.'

??Die Ratte wurde getötet, weil jemand sie trat.

'The rat was killed because somebody kicked it.'

b. CAUSA FINALIS:

John tötete die Ratte, weil sie ihn anekelte.

'John killed the rat because it disgusted him.'

Die Ratte wurde getötet, weil sie jemanden anekelte.

'The rat was killed because it disgusted somebody.'

This characteristic of weil sentences also shows up with the verbal complexes in question here:

(34) a. ??Sigrid trocknete das Hemd, weil sie es bügelte.

'Sigrid dried the skirt because she ironed it.'

a.' ??Maria zerbrach den Teller, weil sie ihn gegen die Wand schmetterte.

'Maria broke the plate because she smashed it against the wall.'

b. Sigrid trocknete das Hemd, weil es benötigt wurde.

'Sigrid dried the skirt because somebody needed it.'

b.' Maria zerbrach den Teller, weil sie ihn nicht mochte.

'Maria broke the plate because she didn't like it.'

The unacceptability of (33a), (34a), and $\left(34 a^{\prime}\right)$ can be attributed to the fact that the causa efficiens expressed in the subordinate sentences clashes with the direct causal component - also a causa efficiens already inherent in the verbal complexes of the matrix clauses. Consider presumably acceptable counter-examples such as

(35) The flood waters rotted the carpets because the pumps didn't work. ${ }^{16}$

where a causa efficiens in a because sentence seems to go with a transitive causative verb complex with a nonagentive subject. Here, however, it is not the direct source for the change of state in the affected object that is expressed with the because sentence (note the oddity of a corresponding structure like The not working pumps rotted the carpets), but rather a specification of an event-extrinsic cause (see Härtl 2001a) with no direct temporal or spatial link to the result. Now, quite a different picture emerges with regard to the intransitive form of causative verbs. In contrast to the transitive form, they allow weil sentences expressing a causa efficiens not resulting in any oddity: 
(36) a. Das Hemd trocknete, weil Sigrid es bügelte.

'The shirt dried because Sigrid ironed it.'

a.' Das Hemd trocknete, weil der Wind wehte.

'The shirt dried because the wind blew.'

b. Der Teller zerbrach, weil Maria ihn gegen die Wand schmetterte.

'The plate broke because Maria smashed it against the wall.'

c. Das Seil zerriss, weil Petra daran zerrte.

'The rope tore because Petra tugged at it.'

The acceptability of (36) in contrast to (34) is to be ascribed to the compatibility of the causa efficiens (which can also be a natural force as in $\left.\left[36 a^{\prime}\right]\right)$ expressed in the subordinate clause with the matrix clause, which does not inherently express a causa efficiens responsible for the result state of the affected object. Considering the different types of causes sketched above to be conceptual categories, we can conclude now that with decausatives there is no causa efficiens introduced into the discourse set, that is, no direct source of the result encoded in the underlying conceptual structure CS/CT. Notice also that this finding is supported by the oddity of weil sentences expressing a causa finalis subordinated to decausative complexes (cf. [37]). Compare the decausatives again with the passives in (38), which prove to be acceptable:

(37) a. ??Das Hemd trocknete, weil es benötigt wurde.

'The shirt dried because it was needed.'

b. ??Der Teller zerbrach, weil Maria ihn nicht mochte.

'The plate broke because Maria didn't like it.'

(38) a. Das Hemd wurde getrocknet, weil es benötigt wurde.

'The skirt was dried because it was needed.'

b. Der Teller wurde zerbrochen, weil jemand ihn nicht mochte. 'The plate was broken because somebody didn't like it.'

A causa finalis can only express a certain purpose as an independent motivation for an action, which requires some kind of intentionality inherent in the action. Note that the unacceptability of (37) cannot be used to argue that there is no cause at all involved in the meaning of the decausatives - it is only an INTENTIONAL action which cannot be conceptualized as a cause in these examples. However, combined with the argument that decausatives allow a causa efficiens in a weil sentence (cf. [36]), we can conclude that decausatives themselves express neither a causa efficiens (or direct source for the change of state) nor an intentional action causing this very change of state. Events or situations such as those in (37) not containing an intentionality acting entity cannot serve 
a specific purpose. In addition to (37), other nonagentive expressions also show the same behavior in this respect (cf. section 1 above):

(39) a. ??John wusste die Antwort, weil er Maria retten wollte. 'John knew the answer because he wished to rescue Maria.'

b. ??John erblickte das Gemälde, weil er etwas über den Künstler erfahren wollte.

'John saw the painting because he wished to learn something about the painter.'

It is important to note that nonalternating unaccusatives which also expresss the coming about of a result state of an object show similar characteristics. They also allow only weil sentences denoting a causa efficiens (compare [36] to [40]):

(40) a. Die Hütte zerfiel, weil sie dem Regen ausgesetzt war.

'The hut decayed because it was exposed to the rain.'

b. Der Apfel verfaulte, weil er Feuchtigkeit ausgesetzt war.

'The apple rotted because it was exposed to humidity.'

Recall the intuition mentioned above from the conceptual properties of the structures in question: we know from our world knowledge that something must be responsible for the change of state in the affected entity. The examples in (40), being parallel to those in (36), suggest that this type of understood implicit causality inherent in nonalternating intransitive verbs is identical to the type of implicit causality inherent in alternating intransitive verbs. Against this background we can conclude that the preverbal message of decausative and of nonalternating intransitive verbs must be analogous. Both contain a nonreferring causal entity which is sortally and ontologically unspecified (see section 2 for the formal details):

Der Krug zerbricht. Das Haus zerfällt.

CS: BREAK/DECAY(e) \& PROTO-THEME(y, e)

CT: $\quad+$ CHANGE $(y)=\mathrm{e}=$ BREAK $/$ DECAY

$$
[e=\neg \text { DUR \& + TEL] }
$$

$+\operatorname{CAUSE}(\mathrm{x}, \mathrm{e})$

$\neg$ SORT (x) \& $\neg$ REF (x)

$+\operatorname{SORT}(\mathrm{y}) \&+\mathrm{REF}(\mathrm{y})$

The representation implies that although there is a causal component involved in the meaning of the corresponding expressions, the respective entity is not - as the argument above shows - assigned any referential or sortal value and therefore cannot be systematically referred to in language or discourse: the causal component is activated only on the 
basis of knowledge about effects and their source. In contrast, the conceptual properties of passives indicate a concrete causal relationship thus yielding a $\mathrm{CS} / \mathrm{CT}$ in which the sortal features of the causing entity (the agent) are specified or restricted, respectively. With regard to its referential properties, the causing entity can be both: it is either left implicit or referred to in language by means of the various strategies discussed above such as the generation of a by phrase.

Der Krug wurde zerbrochen.

CS: BREAK(e) \& PROTO-AGENT(x, e) \& PROTO-THEME $(y, e)$

$\mathrm{CT}: \quad+\operatorname{CHANGE}(\mathrm{y})=\mathrm{e}=$ BREAK $\quad[\mathrm{e}=\neg \mathrm{DUR} \&+\mathrm{TEL}]$ $+\operatorname{CAUSE}(\mathrm{x}, \mathrm{e})$

$+\operatorname{SORT}(\mathrm{x}) \& \alpha \operatorname{REF}(\mathrm{x})$

$+\operatorname{SORT}(\mathrm{y}) \&+\mathrm{REF}(\mathrm{y})$

The conceptual representation sketched in (41) is processed by the thematic processor thus transforming it into a lexico-semantic target representation SR of decausative verbs as it is given in (27). In spite of the presence of the causal component in the preverbal message, TP is not induced to activate a causative expression containing a lexical CAUSE component. This is due to the fact that the missing sortal and referential specificity of a potentially causing entity must block the assignment of a truth value to a corresponding predicative CAUSE expression on the level of SR. Comparing again (41) with (42) the difference between passives and decausatives with regard to their conceptual properties can now be understood as a difference in the specificity of the causing entities. While in decausatives the demoted entity can be associated with a range of conceptual or sortal domains, this is limited in passives, for with them the causing entity is sortally fixed and the option of a referential determination is given. It is this constellation that allows decausative constructions as Die Vase zerbrach von selbst 'The vase broke by itself', where the sortal kind of the cause is conceptually inaccessible, though some unspecified kind of causing event has to be present. This aspect will be dealt with in more detail in section 3.4.

Crucially, against the background of the examples in (40), I have argued that the conceptual representations for alternating and nonalternating verbal complexes must be analogous, as is illustrated in (41) above. This analysis is challenged by recent studies on the comprehension of verbal complexes like the ones in question here. McKoon and Macfarland (2000) conducted reading studies where participants were presented sentences containing intransitive verb complexes corresponding roughly to the alternating verbs described here on the one hand and 
intransitives corresponding to the group of nonalternating verbs on the other. ${ }^{17}$ For each sentence, participants were asked to decide whether the sentence is acceptable or not. The statistical analysis shows that judgment times were significantly longer (namely about $160 \mathrm{~ms}$ ) for structures like the residents awoke (=external causation, see footnote 17) than for sentences like the flowers bloomed (=internal causation). According to McKoon and Macfarland, this difference is due to the higher degree of lexico-semantic complexity of awoke as compared to bloom: even in their intransitive use, the authors conclude in contrast to the analysis presented above that only external causation verbs contain two subevents, that is, a CAUSE event with an unspecified causer and a BECOME event denoting the change of state that the internal argument is subject to. I doubt, however, whether this conclusion can be drawn. First, we know from a number of studies on the comprehension and production of supposedly more or less complex decompositional structures that hardly any differences in the processing of the corresponding linguistic material can be detected (cf. de Almedia 1998; Fodor et al. 1975; Roelofs 1997). This does not necessarily imply that the concept of lexical decomposition itself is to be abandoned. Jackendoff (1983) argues that a higher complexity might, in fact, result in a facilitation of cognitive processing, because more complex structures (for instance highly complex musical sequences) seem to be stored in larger chunks, which can be accessed more easily than several smaller units (cf. also Härtl 2001a). This perspective is supported by recent functional magnetic resonance imaging studies (see Dogil 1999) on the production of phonetic sequences like/ta ka pa/ or /tagebau/ as compared to a single unit like /ta/: it is the latter which evokes higher cognitive activity measured by the supply of blood to specific areas of the brain. Thus McKoon and Macfarland's findings with respect to higher reaction times found for external causation verb structures could, in fact, also be interpreted as a reflex of a lower complexity. Moreover, another kind of explanation for the difference detected by McKoon and Macfarland is conceivable: as it lies in the nature of the structures in question, external causation verb complexes in their intransitive use show a higher tendency than internal verb complexes to be temporally ambiguous. This is so because the noun phrase in subject position can initially be interpreted as a causer and only later reanalyzed as the theme argument of the change of state. Example sentences from the material used in McKoon and Macfarland (2000) are: the residents awoke ..., the fan vibrated ..., the bullet splintered ... . This ambiguity is given to a much smaller extent with the verbs the authors classify as internal causation verbs (the roof deteriorated ..., the metal corroded ..., his knees swelled ...). Therefore, the difference in reaction time could, in 
principle, also be attributed to an AGENT-first principle (cf. Ferreira 1994; van Nice and Dietrich [n.d.]) initially triggering a transitive reading with the external causation verbs which is blocked more effectively with the internal causation verbs. In general, we can conclude that the results in McKoon and Macfarland (2000) do not convincingly force the conclusion that there are fundamental differences in the lexico-semantic or the conceptual properties of the two intransitive verb groups.

Having explored the lexical and conceptual characteristics of the decausative (inchoative) form, the question as to which specific properties the restriction on the alternation is based upon still needs to be answered: what is it that allows only a subset of change-of-state events to be realized either transitively or intransitively? With regard to the representations in (41) and (42), this will motivate the different types of referential specifications of the causing entity and determine the specific knowledge structures underlying the actual conceptualizations of the events in equation. I shall address this issue in the final section concentrating on a selection of possible realizations of change-of-state verbs.

\subsection{Restricting the options: knowledge about changes of state}

The issue discussed here is complex, for we have to contrast those structures forbidding a referential specification of a causal entity (cf. [43a]) with those which realize it as obligatory (cf. [43b]) and to compare both with the alternating verbs (cf. [43c]):

(43) a. Es verfällt/verfault/verrostet/verkommt/verwittert/ verlottert/verschleißt.

*Hans verfällt/verfault/verrostet/verkommt/verwittert/ verlottert/verschleißt es.

'Hans decays/rots/rusts/dilapidates/weathers/runs it down/ wears it out.'

b. Hans zerschmettert/zerstört/verfeuert/verstümmelt/ zerstößt/verschüttet es.

*Es zerschmettert/zerstört/verfeuert/verstümmelt/zerstößt/ verschüttet.

'It shatters/destroys/burns/mutilates/crushes/spills.'

c. Peter verbrennt/trocknet/taut/rollt es.

Es verbrennt/trocknet/taut/rollt.

'It burns/dries/thaws/rolls.'

Note that the nonalternating verbs in (43a) canonically denote incremental changes of state, that is, gradual processes with a certain duration 
before the endpoint is achieved. This event structure is also exhibited by alternating verbs of the type in (43c). So what distinguishes the two groups? This is a question which concerns general episodic knowledge structures (a subset of CKB) underlying the events to be conceptualized and which is therefore not necessarily part of the preverbal message itself.

Both the verbs in (43c) and (43a) denote in their intransitive use incremental processes or changes ${ }^{18}$ which are not caused directly by a specific entity but by entities from more abstract domains such as temperature, humidity, or oxidation. The two groups differ, however, with regard to the event that initiates the incremental process of the change in the object. While with alternating expressions of the type (43c) it is possible to associate a canonical activity, no such canonical activity can be conceptualized with verbs as verfallen, verfaulen, or verrosten in (43a). With the latter verbs it is rather something like the environmental condition that causes the change of state to come about, while with verbs like verbrennen or trocknen there can be concrete activities such as [IGNITE y] or [EXPOSE TO WARMTH y] by which the corresponding process is initiated. This activity can be identified in space and time. The schema in Figure 1 illustrates the difference:
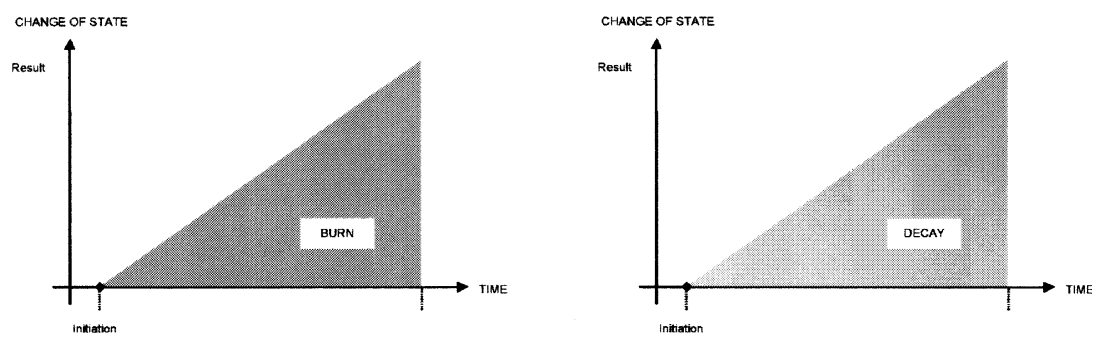

Figure 1. Initiation, progress, and results of a BURN event and a DECAY event

The conceptual inaccessibility of an initiating activity illustrated in Figure 1 explains the oddity of structures that incorrectly focus on such an activity. An example of this constellation is given with a reflexive modifier as von selbst 'by itself', which erroneously implies that there could have also been an external activity causing the corresponding change in the object:

(44) a. $\S \S$ Der Apfel verfaulte von selbst.

'The apple rotted by itself.'

a.' $\S$ Das Holzstück verwitterte von selbst.

'The piece of wood weathered by itself.' 
The somewhat intuitive idea about a canonical or stereotypical activity being conceptually associated with the changes of state expressed in (43c) but not with those in (43a) may be strengthened when taking into consideration current psychological studies on the mental encoding of the temporal relation between certain events. Krüger and van der Meer (1999) investigated the representation of the temporal order of specific events that are related to each other as [IGNITE $\rightarrow$ BURN $\rightarrow$ EXTINGUISH]. The authors concluded on the basis of results from eye-tracking experiments that the temporal order of only highly typical event sequences is stored in long term memory (or CKB in the model used here). Consequently, in the case of the verbal expressions in (43a) not being associated with a canonical causing event no such relation is expected to be represented in a stationary knowledge structure. ${ }^{19}$

Why do verbs of the group in (43b) like verstümmeln 'mutilate' or zerstören 'destroy' not detransitivize? They can denote incremental processes too and obviously express a concrete activity. In this case, the difference lies in the change of state itself. The verbs in (43a) and (43c) express changes of an object property that depends on the object's inherent constitution or that related to an inherent property of an object such as its molecular structure, which is inaccessible to naïve physical reasoning and which cannot be changed intentionally to serve a certain purpose: when somebody burns a piece of paper he or she is not the direct source of the whole burning at every time in the progress of the event but only an initiator of an independently progressing event. However, with verbs like verstümmeln (see [43b]) each single subprogress in the entire event depends on the impact of a concrete outer force. This means that here a causing event not only initiates a change in the object but the entire change must be triggered by a discharge of some concrete power at all times in the progress of the event - as, for example, in the course of the destruction of an oil painting by painting it over step by step (cf. Figure 2). An object cannot become mutilated or destroyed by itself, for in this process an object property such as shape or location is affected, which is subject to the (innate) cognitive principle of cohesion, where cohesion dictates that objects maintain their rigid boundaries (cf. Spelke et al. 1995).

Note that the causing event and the change of state can also be punctual in their temporal structure as is the case with expressions like The rock destroyed the hut. With them the same conditions hold as with the incremental changes: the causing event and the change in the object still coincide temporally, and the completion of the change of state depends on the impact of the causing entity. 


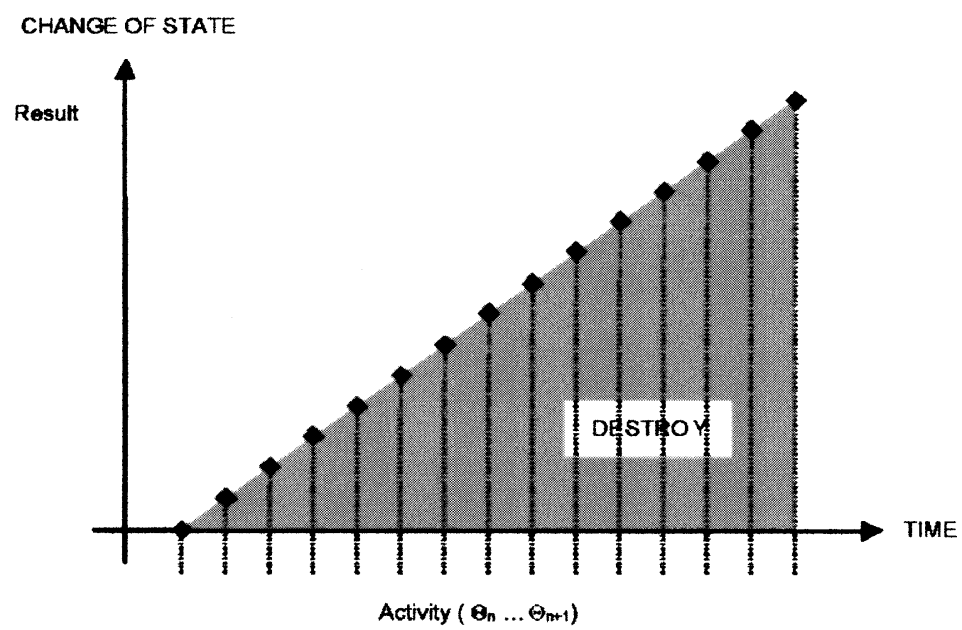

Figure 2. Constant impact on the object during a DESTROY activity

The difference between verbs that denote changes whose completion is entirely dependent on the causing entity and verbs that can express independent changes is reflected in constructions that indicate an interruption of the causing action. These are acceptable with the former type, that is, verbs of the destroy type (John continued destroying the painting) but less acceptable with the latter (??John continued burning the house). It is apparent that with verbs of the destroy type, a conceptual exclusion of the causing activity rendering a decausative structure would result in a paradoxical event conceptualization: decausativization entails that an object property changes independently ${ }^{20}$ but the verbs in (43b) describe changes that are consistently due to some concrete outer force.

So far, I have not said anything about alternating verbs also belonging to the group (43c), that is, verbs of the type zerbrechen 'break' or zerreißen 'tear apart', with which a canonical causing activity can be associated but which, from an intuitive perspective, do not seem to denote a change that can come about independently. In principle, their characteristics prove to be quite similar to the burn verbs discussed above: with zerbrechen and zerreißen events, a canonical causing activity can also be associated. Unlike burn, however, verbs like zerbrechen oder zerreißen denote a punctual change of state, which coincides temporally with the canonical activity:

So what is the difference between punctual zerstören (cf. [43b] and above) and zerbrechen then? I shall assume that verbs like zerbrechen and zerreißen are underspecified with regard to the kind of object property 


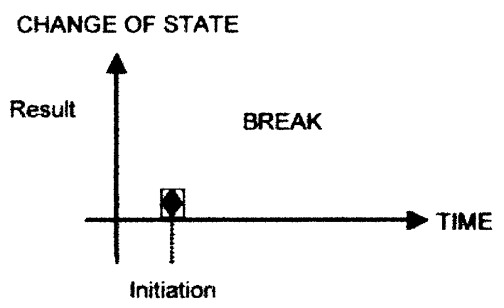

Figure 3. Cause and effect in a BREAK event

to which the change of state refers: the change can either relate to an inherent object property, which can change independently, or it can refer to an object property which can be changed only through the impact of a concrete outer force. Evidence comes from distinct selectional restrictions on the affected object in either the transitive or the intransitive, decausative use:

(45) a. Hans zerriss das Bild.

'Hans tore apart the picture.'

??Das Bild zerriss.

'The picture tore apart.'

b. Hans zerriss das Seil.

'Hans tore apart the rope.'

Das Seil zerriss.

'The rope tore apart.'

The examples show that the concepts in question can only be realized intransitively if the affected object meets certain selectional restrictions: in the intransitive use there has to be an object with inherent properties that can change independently. Consequently, these verbs can express both a change in an inherent property coming about independently and a change that can only be caused by some concrete force.

As the discussion above suggests, a computation of three distinctive conceptual features seems to underlie the choice of an adequate lexical entry that correctly encodes the corresponding conceptual constellation. In summary, these features indicate instantiations of the following issues: (i) Does the change of state refer to an INHERENT OBJECT PROPERTY? (ii) Can the change of state be associated with a CANONICAL, INITIATING ACTIVITY? (iii) Is it an INCREMENTAL change of state? A crosswise combination of the respective feature instantiations gives the following results (with $\alpha$ indicating opacity with regard to a feature specification): 
Table 1. Conceptual feature specification of changes-of-state events

\begin{tabular}{lllll}
\hline & $\begin{array}{l}\text { INHERENT } \\
\text { PROPERTY }\end{array}$ & $\begin{array}{l}\text { CANONICAL } \\
\text { ACTIVITY }\end{array}$ & $\begin{array}{l}\text { INCREMENTAL } \\
\text { CHANGE }\end{array}$ & $\begin{array}{l}+/- \text { LEXICAL } \\
\text { ALTERNATION }\end{array}$ \\
\hline $\begin{array}{l}\text { verbrennen, trocknen, tauen } \\
\text { (burn, dry, thaw) }\end{array}$ & + & + & + & ALTERNATES \\
$\begin{array}{l}\text { zerbrechen, zerreißen } \\
\text { (break, tear apart) }\end{array}$ & $\alpha$ & + & - & ALTERNATES \\
$\begin{array}{l}\text { verfaulen, verfallen, verrosten, } \\
\text { verwittern } \\
\text { (rot, decay, rust, weather) }\end{array}$ & + & - & + & $\begin{array}{l}\text { INTRANSITIVE } \\
\text { ONLY }\end{array}$ \\
$\begin{array}{l}\text { zerstören, zerschmettern, } \\
\text { zerstoßen, verstümmeln } \\
\text { (destroy, crush, pulverize, } \\
\text { mutilate) }\end{array}$ & - & + & $\alpha$ & TRANSITIVE \\
\hline
\end{tabular}

Note that a negative specification of both [INHERENT PROPERTY] and [CANONICAL ACTIVITY] renders an impossible event conceptualization for in this case an object property would change independently that can only be changed under the influence of some concrete force. This requirement rules out the decausativization of destroy verbs.

To summarize this section, we can conclude that the extralinguistic episodic knowledge underlying intransitive decausative verbs must indicate that the corresponding change of state can be conceptualized as being caused by an initiating activity involving a specific entity (= CHANGE(x) with $x$ being the causing entity in [46]). This information is part of the conceptual knowledge base and need not be activated necessarily in the actual conceptualization process:

LEXICALLY ALTERNATING:

$\mathrm{CT}_{\text {ES-СKB }}: \mathrm{BURN}$ (newspaper)

$:[$ CHANGE $(\mathrm{x}) \rightarrow \mathrm{BURN}($ newspaper)] $+/ \neg \operatorname{SORT}(\mathrm{x}) \&$ $+/ \neg \operatorname{REF}(\mathrm{x})$

While similar-meaning postulates might also characterize the concepts realized by obligatorily transitive or intransitive verbs, it is only the concept of the alternating verbs in which the sortal and referential specification of the causing entity is left indeterminate. This is a conceptual condition that has its motivation in the conceptual feature classification discussed above. Accordingly, the two concepts resulting in nonalternating transitive and intransitive verbs have to specify the referential status of a potential causing entity either positively or negatively (cf. [41] and [42] above): 
ONLY INTRANSITIVE:

$\mathrm{CT}_{\mathrm{ES}-\mathrm{CKB}}: \mathrm{DECAY}($ wood $)$

: [CHANGE(x) $\rightarrow$ DECAY (wood)]: $-\operatorname{SORT}(\mathrm{x}) \& \neg \mathrm{REF}(\mathrm{x})$

(48) ONLY TRANSITIVE:

$\mathrm{CT}_{\mathrm{ES}-\mathrm{CKB}}$ : DESTROY (painting)

$:[\operatorname{CHANGE}(\mathrm{x}) \rightarrow \operatorname{DESTROY}($ painting)]: $+\operatorname{SORT}(\mathrm{x}) \&$

$\neg \mathrm{REF}(\mathrm{x})$

In the course of the conceptualization of the events in question, the conceptualizer has to process these instructions thus specifying the referential status of potential event participants and controlling their accessibility in the current discourse. The referential requirements are realized in grammar by the thematic processor, which triggers a selection of suitable lexical items matching the referential constellations.

Some verbs may not be covered by the system, for example, zersplittern 'shatter', 'split into pieces', which is somewhat odd though not completely out when used transitively. In principle, it should fit into the [TRANSITIVE ONLY]-group (cf. Table 1 above) without any problem for it describes a (punctual) change of state referring to a propery that can only be affected by some specific outer force. Problematic cases like these, which need to be explained in more detail, vividly illustrate what has been mentioned above: the complex issue of argument alternation and its conceptual motivation cannot be explained simply on the basis of a binary attribute as has been sometimes suggested in the literature (cf. section 3.1) but by a combination of several factors which complement each other, thus covering the variability in meaning that causative verbs show.

\section{Conclusion}

The results of the discussion in this paper are to be summarized as follows. To begin with, the formulator produces a lexical representation SR of intransitive decausative verbs, which in contrast to passives does not encode a causal component. Thus on the level of grammar or lexical meaning there is no indication - neither explicitly nor implicitly — of a potential causal relation between two entities. This parallels the conceptual input structure, that is, the preverbal message, in so far that it is assembled by the conceptualizer such that no causal entity is introduced into the current discourse set. Therefore in discourse a corresponding casual entity is not accessible. Instead, the causal relation intuitively understood with intransitive verbs as verbrennen 'burn' or break 'zer- 


\section{H. Härtl}

brechen' equals the causal implication of nonalternating intransitive verbs such as verfallen 'decay': both express an abstract cause, which cannot be identified sortally or referentially on the basis of current discourse information and which does not enter the linguistic representation. This constellation is reflected in grammar such that both alternating verbs in their intransitive use as well as nonalternating intransitives are assigned analogous, monadic lexico-semantic representations. With both types only the change of state is encoded without the addition of a causal component to the linguistic representation.

In principle, the conceptual difference between passive and decausative has to be characterized as a difference in the sortal specificity of the causing entity and its referential identity. Concerning the several types of decausatives themselves, in contrast to a decay event, in a burn event a specific agentive entity can be conceptualized, for the latter represents a gradual progress, which can be associated with a concrete initiating event that can be identified in space and time. This event initiates a change in an object that can - due to the inherent properties of the object - progress independently. No such independent progress can be conceptualized with verbs such as zerstören 'destroy', which can also denote a gradual change in an object property. This property, however, cannot alter at any point in the progress of the event without a discharge of some external force. Thus a decausativization would generate incorrect inferences about the properties of the affected object. With break events a canonical activity can also be associated, with them, however, the type of object property that the change refers to is underspecified and depends on the object type. As can be seen, a combination of the several features is necessary to determine the characteristics of a plausible preverbal message underlying change-of-state verbs and its possible grammatical realizations.

Received 14 June 2001

Humboldt University, Berlin

Revised version received

11 January 2002

\section{Notes}

* The work that I am reporting on in this paper has been realized in the project "Conceptual transfer of situations into verbal meaning" (OL 101/2-2, headed by Prof. Dr. Susan Olsen). It is part of the priority program "Language Production" funded by the Deutsche Forschungsgemeinschaft (DFG). The paper has been completed in the DFG project "Compula-Predicative Constructions" (headed by Prof. Dr. Ewald Lang) at ZAS, Berlin. For discussion and useful hints, I wish to thank the participants of the 
workshop "Conceptualization" in Heidelberg (February 2000) and Veronika Ehrich, Susan Olsen, Chris Piñón, Tolja Strigin, Jim Witt, and two anonymous reviewers. Correspondence address: Institut für Anglistik und Amerikanistik, Humboldt Universität, Unter den Linden 6, 10099 Berlin, Germany. E-mail: holden. haertl@rz.hu-berlin.de.

1. I use the term "decausative" to make clear that the verb in question has a causative counterpart. I will not discuss the derivative relation between the transitive and intransitive form. I shall refer the reader to Piñón (2001a) for discussion.

2. The conceptualizer can be associated with working memory insofar as it reacts to perceptual stimuli and keeps all necessary information active in order to respond appropriately.

3. Note that the term prelinguistic is not supposed to imply any kind of processing direction. So far general aspects of language production as well as language comprehension are covered.

4. For the details that rely on psychological findings as they are presented in Spelke et al. (1995), see Dowty (1998) and Härtl (2001a).

5. The term thematic processor is related to psycholinguistic findings as presented in Rayner et al. (1983) and Frazier (1987). According to these works, the thematic processor regulates the second stage of language processing (so-called second pass parse). The idea is that at this stage a linguistic representation that has been established by the parser up to this point can be revised on the basis of extralinguistic information. Frazier (1987) points out that the thematic processor has access to argument structural properties of the linguistic expression, to its thematic structure as well as to pragmatic background knowledge. In this sense, the thematic processor is able to translate certain pieces of information and map them onto the adjacent level.

6. SR has been formulated in the so-called two-level semantics (cf. Bierwisch 1986 and Bierwisch and Lang 1989). It allows one to define exactly those components that are visible in syntax and prevents an inflation of meaning representations of lexical entries that adjust their meaning under certain contextual conditions.

7. The SR representation is a translation of the lexico-semantic structure in Levin and Rappaport Hovav (1995: 108). " $\varnothing$ " represents LEXICAL BINDING, its formal status being unclear. The predicate INST anchors an event variable e in the semantic representation of a verbal complex. INST can be seen as a reflex of the Davidsonian idea that verbs contain a situational variable in their logical structure (cf. Maienborn 1996). In type logical terms INST is of type $<\mathrm{t},<\mathrm{e}, \mathrm{t}>>$.

8. Recall that SR encodes only those parts of meaning that are grammatically relevant (see section 2 above).

9. This does not imply that the causal entities reintroduced with the dativus (in-)commodi are agentive in the narrow sense of intentionality, in fact they are often considered nonagentive (cf. Abraham 1995).

10. Notice that the dative can also be interpreted benefactively in this structure: Peter broke the plate for John (cf. Wunderlich 1996). This reading is not discussed here.

11. In this simplified representation, punctuality is not encoded explicitly. There are several ways to reflect the temporal progress of the change of state. Rapp (1997), for instance, introduces the semantic constant DEV to denote durative changes of state in contrast to punctual ones for which she uses BECOME instead. I cannot go into the several details of this issue here.

12. I wish to thank an anonymous reviewer for this comment.

13. Not only change-of-state verbs but almost any kind of verb complex can be contrasted in the intended way with a wegen phrase: Mary is dancing. But it isn't because of the 


\section{H. Härtl}

contest but because of the photographer. This is so because the wegen phrase relates complete events to its indirect cause, origin, or purpose.

14. For a discussion of different types of the specificity of unexpressed arguments see Jacobs (1993). In his terms in passives there is an implicit but sortally specific argument.

15. Instead of causa efficiens subordinated to a decausative complex in German has to be realized with indem. This means that clauses directly related to an unspecific cause (to be exact: a causa efficiens), thus only explicating it: John killed the rat by poisoning it.

Alternatively, a causa finalis can also be realized with $d a$ or with an infinitive purpose clause $u m z u$. I shall not discuss the several options of the usage of conjunctions here. What is especially relevant is the finding that the ambiguous conjunction weil is restricted in its usage dependent on the type of the causal relation between two states of affairs.

16. I wish to thank an anonymous reviewer for this example.

17. Note that the authors make use of the concepts "external" and "internal causation" (cf. Levin and Rappaport Hovav 1995 and section 3.4), which I associate with alternating and nonalternating verbs here. On the basis of corpus data, however, the authors argue that it is rather the sortal restrictions on the transitive subject of causation verbs that provide a diagnostic for distinguishing external from internal causation verbs.

18. In fact these changes can be characterized as an indefinite set of "microchanges" thus constituting an incremental process as a whole (cf. Dowty 1979; Härtl 2001a; Jackendoff 1996; Tenny 1994).

19. With regard to the issues discussed here, an additional condition is required: two events ordered temporally as described above need to be in a direct causal relation. Thus only the temporal sequence [IGNITE $\rightarrow$ BURN] is relevant here for there is a causal relation between the two, while no such relation holds between [BURN $\rightarrow$ EXTINGUISH].

20. "Independently" - as mentioned above — does not imply that there is no cause at all. The notion rather refers to a change that is caused by some conceptually nonreferring or inaccessible entity such as temperature, pressure, or humidity.

\section{References}

Abraham, Werner (1995). Deutsche Syntax im Sprachenvergleich. Studien zur deutschen Grammatik 41. Tübingen: Narr.

Almeida, Roberto D. de (1998). Lexical concepts do not decompose: evidence from verbs. Paper presented at the Archictures-and-Mechanisms-for-Language-Processing conference. Freiburg, Germany.

Bierwisch, Manfred (1986). On the nature of semantic form in natural language. In Human Memory and Cognitive Capabilities. Mechanisms and Performances, Friedhart Klix and Herbert Hagendorf (eds.), Vol. B, 765-784. Amsterdam: Elsevier.

-; and Lang, Ewald (eds.) (1989). Dimensional Adjectives. Grammatical Structure and Conceptual Interpretation. Berlin: Springer.

-; and Schreuder, Robert (1992). From concepts to lexical items. Cognition 42, 23-60.

Burzio, Luigi (1986). Italian Syntax. A Government and Binding Approach. Dordrecht: Reidel.

Chierchia, Gennaro (1989). A semantics for unaccusatives and its syntactic consequences. Unpublished manuscript, Cornell University. 
Dogil, Greg (1999). Neuroanatomie der Sprachproduktion. The more complex the more focused hypothesis. Paper presented at the workshop "Language Production," Osnabrück, Germany.

Dowty, David (1979). Word Meaning and Montague Grammar. The Semantics of Verbs and Times in Generative Semantics and in Montague's PTQ. Dordrecht: Reidel.

-(1991). Thematic proto-roles and argument selection. Language 67, 547-619.

- (1998). On the origin of thematic role types. Full handout of a paper presented at the conference "Lexicon in Focus." Wuppertal, Germany.

Ferreira, Fernanda (1994). Choice of passive voice is affected by verb type and animacy. Journal of Memory and Language 33(6), 715-736.

Fodor, Janet D.; Jerry A. Fodor; and Merrill Garrett (1975). The psychological unreality of semantic representations. Linguistic Inquiry 6(4), 515-531.

Frazier, Lyn (1987). Theories of sentence processing. In Modularity in Knowledge Representation and Natural-Language Understanding, Jay Garfield (ed.), 291-307. Cambridge, MA: MIT Press.

Härtl, Holden (2001a). CAUSE und CHANGE: Thematische Relationen und Ereignisstrukturen in Konzeptualisierung und Grammatikalisierung. Studia grammatica 50. Berlin: Akademie.

- (2001b). Mapping conceptual onto grammatical structures: the case of psych-verbs. In Structural Aspects of Semantically Complex Verbs, Nicole Dehé and Anja Wanner (eds.). Frankfurt: Peter Lang.

- (2003). The conceptual inactiveness of implicit arguments: evidence from particle verbs and object categorization. Journal of Semantics 20(1), 1-35.

-; and Witt, James (1998). Lokale Konzepte und Partikelverben in einem Modell der Sprachproduktion. Zeitschrift für Sprachwissenschaft 17(1), 3-34.

Herweg, Michael; and Maienborn, Claudia (1992). Konzept, Kontext, Bedeutung. Zur Rolle der Zwei-Ebenen-Semantik in einem Modell der Sprachproduktion. In Hamburger Arbeitspapiere zur Sprachproduktion I. Arbeitspapier 9, Michael Herweg (ed.), 7-31. Hamburg: Graduate Program "Kognitionswissenschaft."

Houssiadas, Lambros (1964). An Exploratory Study of the Perception of Causality. The British Journal of Psychology. Monograph Supplements 36. London: Cambridge University Press.

Jackendoff, Ray (1983). Semantics and Cognition. Cambridge, MA: MIT Press.

-(1996). The proper treatment of "measuring out". Telicity, and perhaps even quantification in English. Natural Language and Linguistic Theory 14, 305-354.

Jacobs, Joachim (1993). The Lexical Basis of Optional Complements. Arbeiten des SFB 282 "Theorie des Lexikons" 53. Wuppertal: Bergische Universität.

Kaufmann, Ingrid (1995). Konzeptuelle Grundlagen semantischer Dekompositionsstrukturen. Die Kombinatorik lokaler Verben und prädikativer Komplemente. Linguistische Arbeiten 335. Tübingen: Niemeyer.

Krüger, Frank; and van der Meer, Elke (1999). Die Repräsentation von Zeitbezügen im begrifflichen Wissen. In Experimentelle Psychologie. Beiträge zur 41. Tagung experimentell arbeitender Psychologen, Eric Schröger et al. (eds.), 337. Lengerich: Pabst Science Publishers.

Lang, Ewald (2000). Adversative connectors on distinct levels of discourse: a re-examination of Eve Sweetser's three-level approach. In Cause - Condition - Concession - Contrast. Cognitive and Discourse Perspectives, Elizabeth Couper-Kuhlen and Bernd Kortmann (eds.), 235-256. Berlin: Mouton de Gruyter.

Levelt, Willem J. M. (1989). Speaking. From Intention to Articulation. Cambridge, MA: MIT Press. 
Levin, Beth; and Rappaport Hovav, Malka (1995). Unaccusativity. At the syntax-lexical semantics interface. Cambridge, MA: MIT Press.

Maienborn, Claudia (1996). Situation und Lokation. Die Bedeutung lokaler Adjunkte von Verbalprojektionen. Studien zur deutschen Grammatik 53. Tübingen: Stauffenburg.

Mauner, Gail; and Koenig, Jean-Pierre (2000). Linguistic vs. conceptual sources of implicit agents in sentence comprehension. Journal of Memory and Language 43, 110-134.

McKoon, Gail; and Macfarland, Talke (2000). Externally and internally caused change of state verbs. Language 76(4), 833-858.

Nice, Kathy van; and Dietrich, Rainer (n.d.). Animacy effects in language production: from mental models to formulator. In Structures and Processes at the Syntax-Semantics Interface, Holden Härtl and Heike Tappe (eds.). Berlin: Mouton de Gruyter.

Olsen, Susan (1997). Der Dativ bei Partikelverben. In Festschrift für Heinz Vater, Christa Dürscheid, Monika Schwarz, and Karl-Ramers (eds.), 307-328. Tübingen: Niemeyer.

Pasch, Renate (1983). Die Kausalkonjunktionen "da", "denn" and "weil". Drei Konjunktionen - drei lexikalische Klassen. Deutsch als Fremdsprache 20(6), 332-337.

Perlmutter, David (1978). Impersonal passives and the unaccusative hypothesis. In Proceedings of the Fourth Annual Meeting of the Berkeley Linguistic Society, Jeri Jaeger et al. (eds.), 157-189. Berkeley: University of California.

Piñón, Christopher (2000). The causative alternation in an event semantics. Handout of a paper presented at the Workshop "Event Semantics", University of Leipzig.

- (2001a). A finer look at the causative-inchoative alternation. In Proceedings of Semantics and Linguistic Theory 11, Rachel Hastings, Brendan Jackson, and Zsofia Zvolenszky (eds.). Ithaca, NY: CLC Publications, Cornell University.

- (2001b). Modelling the causative-inchoative alternation. Linguistische Arbeitsberichte 76, 273-293.

Rapp, Irene (1997). Partizipien und ihre semantische Struktur. Zu passivischen Konstruktionen mit dem 3. Status. Studien zur Deutschen Grammatik 54. Tübingen: Stauffenburg.

Rayner, Keith; Carlson, Marcia; and Frazier, Lyn (1983). The interaction of syntax and semantics during sentence processing. Journal of Verbal Learning and Verbal Behavior 22, 358-374.

Roelofs, Ardi (1997). A case for nondecomposition in conceptually driven word retrieval. In Journal of Psycholinguistic Research 26, 33-67.

Roeper, Thomas (1987). Implicit arguments and the head-complement relation. Linguistic Inquiry 18, 267-310.

Spelke, Elizabeth; Phillips, Ann; and Woodward, Amanda (1995). Infants' knowledge of object motion and human action. In Causal Cognition. A Multidisciplinary Debate, Dan Sperber, David Premack, and Ann Premack (eds.), 44-78. Oxford: Clarendon.

Tenny, Carol (1994). Aspectual Roles and the Syntax-Semantics Interface. Studies in Linguistics and Philosophy 52. Dordrecht: Kluwer Academic Press.

Wunderlich, Dieter (1996). Dem Freund die Hand auf die Schulter legen. In Wenn die Semantik arbeitet, Gisela Harras and Manfred Bierwisch (eds.), 331-360. Tübingen: Niemeyer. 